peculiarities of small forms of $O$. Honchar's journalism, in particular the genre of the essay. The problems of the theory of artistic and non-fiction genres are emphasized. It is proved that the peculiarities of genre creation and transformation of the genre structure of small epic forms into O. Honchar's works were conditioned by the emergence of new themes that actualized national, social, moral and ethical, aesthetic problems of society, which required adequate form and means of artistic embodiment. It is established that $O$. Honchar, in small prose, adhered to the principles of realism, romanticism, psychologism, documentalism and focused on the writing tradition of the late XIX - early XX centuries with a peculiar narrative and, at the same time, entered the confluence of European and world literatures with their inherently narrative experimentation.

Key words: genre, novel, story, essay, prose, publicistic writing.

Дата надходження статті: «14» листопада 2019 р.

Дата прийняття до друку: «24» грудня 2019 р.

УДК 821(4-11).09»197/178»

DOI: 10.31475/fil.dys.2020.10.04

ДМИТРО дРОЗДОВСькИЙ, кандидат ббілологічних наук

(л. Київ)

\title{
Дискурс транскультурації в сучасних британських романах: ревізія архетипу Долу
}

Теорія транскультурності (Ф. Ортіс) набуває особливої значущості в річищі сучасного літературознавства й культурологї, об’ктали яких є гібридні культурні явища. Транскультурність залішує мультикультуралізл, який не передбачає трансферу сенсів, иінностей, досвіду, культурних фбеноленів тощо, а лише утверджує їх наявність в одному геополітичному й соціокультурному полі. Транскультурність дае можливість розглядати культурні артеббакти як складні явища, позначені іланентною неоднорідністю ü негологенністю, що водночас $i$ забезпечує особливу креативну иінність і культурну значущість таких фбеноленів. У вітчизнянолу й зарубіжнолу літературознавстві окреслення транскультурацї представлено у працях Г. Бгабги, І. Оржицького, Т. Свербіловой, М. Тлостанової та ін. Проте найчастіше у студіях здійснено історичний огляд бборл становлення дискурсу транскультурацї та 
основних теоретичних концептів (ідей), реалізованих у лоні иього дискурсу. У пропонованій статті, що $\epsilon$ спробою розвитку ідей, належних до дискурсу транскультураиї, йдеться про окреслення архетипу Дому як визначального в літературі концепту й водночас такого, що сьогодні позначений впливол транскультураиї, яка призводить до змішення іманентної сутності иього архетипу в сучаснолу ролані Великої Британї та США. Трансобормації підлягають такі базові уявлення, що корелюють із архетипом Долу, як безпека, захист, колфборт тощо. У роланах, написаних після 2000го р., вихід за межі власного етнічного простору, дає можливість персонажал вийти на новий рівень соціальної безпеки, гарантування иінності власного життя, натолість перебування в межах локусу дому позначене небезпекали й потениійнили загрозали життю. У статті порушено питання про трансборлацію базового архетипу світової культури й літератури в парадиглі постпостлодернізлу. Заміна іманентних рис архетипу Долу співвідноситься з кониептол "залішення" ("displacement»), широко представленолу в сучасній британській теорї літератури.

Ключові слова: архетип Долу, транскультурація, гібридність, теорія літератури, сучасний англоловний ролан, британський ролан.

Постановка проблели в загальнолу вигляді... Сучасний британський роман (синонімом зазначеного поняття «сучасний британський роман» упропонованому дослідженні $€$ термін «постпостмодерністський роман», тобто в часовому плані йдеться про романи, написані після 2000-го р.; «сучасний британський/англійський роман» - термін, зафіксований як у британських працях [8], так і у вітчизняних [3]), як і роман американський, про що свідчать твори I. Альенде (наприклад, «Там за зимою»), уважний до теми переліщень/зліщень/пересувань (в англ. displacement), передусім політичних і сощіокультурних. Переміщення як теоретичне поняття, що визначає один із векторів трансформації британського роману, репрезентовано в «The Routledge companion to twenty-first century literary fiction» [9, с. 240]. У розділі «Displacement» аналізовано концепт «множинного переміщення» на прикладі роману «Пилюка» («Dust», 2014) Івон Едг'ямбо Овуор (Yvonne Adhiambo Owuor). Міграція, тероризм, біженці - образи, що визначають тематичний спектр сучасних романів, написаних після 2000-го р., які по-новому розкривають мотив трансгресії, властивий i постмодерністському 
роману.

Аналіз досліджень $i$ публікацій... Т. Свербілова має рацію, зазначаючи, услід за Вілсоном Гаррісом і Жаком Деррида, що «транскультуращія не стирає відмінності між культурами, а включає їх в творчий ігровий процес» [4, с. 3]. Зазначена тенденція притаманна постмодерністському роману, проте набуває нових ознак і посиленої трансформащійної репрезентації в парадигмі постпостмодерністського роману. Стюарт Голл (Stuart Hall) у книжці «Familiar Stranger» («Свій незнайомець») зауважує, що «переміщення» було «викоренене в його життевий шлях від самого дитинства» [цит. за: 9, с. 243]. «У романі «Exit West» Могсін Гемід оприявнює складність відносин між домом/безпекою та переміщенням/вразливістю через сконструйовані ним домашні простори» [9, с. 243].

Трансгресія як художній мотив передбачає вихід за межі, проте в постпостмодернізмі важить не просто сам вихід i розширення меж, а пошуки сенсів у новій реальності (наприклад, геополітичній), до якої потрапляють персонажі, тікаючи зі свого долу, як у британському романі «Вихід на Захід» (Exit West, 2017) Могсіна Геміда (Мохсін Хамід в іншій транслітеращї; англ. Mohsin Hamid). Мотив утечі реалізує дискурс транскультурності, що $є$ ще одним чинником постпостмодерністського роману Великої Британії. Крім того, «поняття транскультурності може бути використаним як основа для сучасного компаративного аналізу літератури» [4, с. 1].

Водночас ідея транскультурності в романах часто експлікована у формах переміщень персонажів, які, потрапляючи до нової країни, формують новий тип ідентичності, що не є моноетнічною. Часто сам спосіб бачення сощіополітичної реальності в романах позначений впливом доктрини Global Care [6; 7], що передбачає центральність етичних принципів у формуванні сучасної глобальної політики. Така політична доктрина, яка має значний вплив на фрормування сучасної геополітики, розроблена на основі уявлень про стосунки на інтерперсональному рівні, що водночас передбачає увагу до таких явищ, як геополітичні стереотипи, упередження тощо (наприклад, відмінності між південними й північними типами менталітету представників Європи тощо). На думку Т. Свербілової, «особливої уваги заслуговує дослідження динаміки фрормування транскультурного феномену в сучасній літературі - тієї їі складової, що раніше вивчалась крізь призму етнічного, та аспектів транскультурного, які призводять до створення літературного твору, що за тематикою, проблематикою та поетикою є складним феноменом» [4, с. 9]. 
Доктрина Global Care передбачає наявність відповідальності усіх гравців геополітичної арени за визначення економічної, соціальної політики у світі: кожний гравець відповідальний не лиш за себе, а й за іншого. Можна погодитися, що ця політична теорія в своїй основі має, зокрема, імагологічну основу, оскільки відносини між країнами проектуються на основі вивчення стосунків між людьми, що представляють різні культурні регіони. Ідеї концепщії Global Care представлені в сучасних британських романах постпостмодерністського періоду. Так, Генрі Пероун у «Суботі» I. Мак'юена аналізуе тероризм як виклик XXI століття. Проте пояснення цього феномену для нейрохірурга в романі має медичну основу (припущення), що цілком відповідае загальним тенденціям постпостмодерністського роману (явища сприймаються i розглядаються в сцієнтистській парадигмі, аналітично й раціонально [див.: 2]), проте Генрі замислюеться над нерівномірністю розподілу благ у сучасному світі, що викликає в певних груп фанатичні устремління, які штовхають найбільш запеклих франатиків до терористичних атак. Т. Свербілова зазначає: «Хомі Бгабга стверджує, що світову літературу необхідно розглядати через призму таких загальних тем, як історична травма, рабство, геноцид, вигнання, втрата культурної ідентичності» [4, с.4]. Поділяючи цю тезу й такий підхід, зауважу, що зазначений перелік понять варто доповнити й поняттям «тероризм», що має стосунок до дискурсу транскультурації $є$ чинником розбудови політики Global Care, що має допомогти спільними зусиллями подолати цю планетарну загрозу..

$$
\text { Форлулюванні иілей статmі... Окреслюючи вектори }
$$
транскультурації та моделі їі репрезентації в сучасних англомовних романах Великої Британії та США, схарактеризувати архетип Долу в парадигмі постпостмодерністського роману.

Виклад основного матеріалу... У романі «Там, за зимою» I. Альенде показано два світи: американський і латиноамериканський, причому останній асоціюеться 3 наркокартелями, торгівлею людьми, рабством тощо. У британських романах простором соціальних проблем і економічних негараздів постають африканські країни, персонажі яких полишають рідну домівку в пошуках кращої в економічному плані долі. Переміщення культурних паттернів, досвіду, взаємодія одного типу ідентичності 3 іншим визначае транскультуральну парадигму сучасного британського роману, у якому персонажі часто оприявнюють погляди, властиві доктрині Global Care, зокрема в аспекті розбудови спільної відповідальності на планеті, наприклад, у тому, що економічно більш розвинуті країни повинні дбати за країни з нижчим рівнем 
соціально-економічного розвитку, дають можливості вихідцях із тих регіонів здобувати кращу освіту, реалізувати себе професійно, культурно тощо. Генрі в «Суботі» I. Мак'юена є прикладом персонажа, котрий сприймає світ як відкритий простір, у якому відбуваються численні переміщення між Сходом і Заходом. Тероризм став однією 3 ліній «переміщення», і персонаж прагне зрозуміти, в чому полягають причинити терористичних атак, які, на перший погляд, постають саме як зіткнення світоглядів i, відповідно, цінностей, сформованих релігією та культурною політикою (на Сході культурна політика часто визначена релігійною доктриною).

Tероризм, як зазначено в «The Routledge companion to twenty-first century literary fiction», спричинився до формування окремої жанрової парадигми в лоні сучасного роману - роман «9/11». 3 одного боку, транскультурність $є$ можливістю здійснити новий розподіл знань, уявлень, відкривши доступ усім до всього (в плані географічних переміщень, мобільності тощо). 3 другого боку, важливо реалізувати концепт переміщень у такий спосіб, щоб сформувати можливість сприймати одне одного, розширюючи за допомогою Іншого межі власного світосприйняття. Цей процес часто зображено в романах як процес зіткнення, проте один із протагоністів роману «Там, за зимою» I. Альенде бачить представників інших культур як носіїв досвіду, який розширюе власні межі пізнання світу. Процес транскультурації передбачає взаємообмін і взаємозбагачення для всіх учасників простору контактів.

Доцільно згадати ідею Гегеля, пов'язану 3 прогресом як просуванням у режимі «+1», коли персонажі розвивають у собі моральність, інтелект, забезпечуючи водночас загальний поступ. Проте процеси транскультурації в реальному світі, пов'язані зокрема 3 доктриною Global Care й репрезентовані в художніх романах, зміщують властиве ще стародавньому світу уявлення про «своє» та «чуже», зокрема в аспекті архетипу Долу. Зазначений архетип, що е одним із базових, піддано трансформації в парадигмі постпостмодернізму. Так, «дім» (простір «свого») тепер зображено як простір небезпек, а інший світ дає персонажам можливість здійснити власний розвиток у царині інтелекту, моралі, культурності тощо.

Архетип Ітаки (різновид архетипу Долу), притаманний загалом европейським літературам, перебуває в стадії трансформащії в сучасному британському роману. Прагнення Одіссея будь-що потрапити до рідної домівки нині заміщуеться прагненням персонажів знайти себе шляхом розламування зв'язків із власним домом, який $є$ 
дискомфортним у економічному плані. Вихід за рамки дому й реалізуе здатність персонажів наблизитися до формування в собі нового типу мислення (глобального), нового світосприйняття та нової ідентичності. У романі «Пилюка» Івон Едг'ямбо Овуор героїня Селен не може втрапити до власного дому, оскільки намагається відчинити двері неправильним ключем» [10, с. 114]. У такий спосіб, на думку Емілі Гог̆', у романі показано «мову дому, бездомності» $[9$, с. 241]. «ї̈ неспроможність відчинити двері символізуе розширене уявлення про те, що вона зайва в цьому місці» [9, с. 241].

Якщо звернутися до вже згаданого образу Ітаки як репрезентації архетипу Дому, то і в цьому образі закладено мотив агону, змагальності та політичних конфліктів, які пов'язані з мандрами Одіссея, який волею богів був змушений полишити дружину Пенелопу й рідну домівку. Конфліктність долу, зіткнення різних політичних груп, боротьба за владу визначае образу дому для сучасних персонажів британського роману, які полишають рідний простір конфліктів, у якому під загрозою опиняеться життя.

Транскультурністьуможливлена геополітичною доктриною Global Care [6; 7], яка передбачає можливість вибору іншого дому й конструювання нової ідентичності, уже не на моноетнічному принципі. Безперечно, для сучасного британського роману цілком справедливим можна вважати твердження Т. Свербілової, що «нові цифрові комунікативні технології і міжнародні мережеві транскомунікативні спільноти ставлять під сумнів існування національних культур i національних держав i змушують переосмислити концепти мультикультуралізму як культурного різноманіття у співіснуванні етнічних культур. Саме за транскультуралізмом, як вважає багато дослідників культури, залишається майбутне» [4, с. 11].

Проте сучасний британський роман оприявнюе зміну в уявленні про «своє» та «чуже», заторкуючи також i архетипного рівня світосприйняття персонажами дійсності.

У постпостмодерністському британському романі представлено зміщення в уявленні про категорію «свій» - «чужий». Якщо традиційно категорія «свій» накладається на образ Долу, що має архетипну природу й асоціюеться з такими поняттями, як затишок і безпека, то в сучасному британському романі категорія «свій» зображена як потенщійно небезпечна, що чатуе на персонажів романів і містить загрозу для їх життів. Персонажі, котрі полишають домівку, залишаються живими, натомість ті, хто лишаються вдома, гинуть від терористичних замахів або внаслідок суспільно-політичних 
заворушень. Зауважу, що таке зміщення $є$ наслідком розвитку мультикультуральної парадигми британського роману XXI ст., у якому одним із елементів зображення художнього простору є топоси, пов'язані 3 автентичною домівкою Іншого: наприклад, ідеться про Кенію як африканську країну, у якій життя людини перебуває під постійною загрозою. Якщо в традиційному уявленні мандрівка в інші світи асоціювалася з потраплянням у небезпеки, то сьогодні це уявлення про вихід за межі дому піддано деструкції й деконструкції загалом. У британській теорї така зміна представлена поняттям «displacement», яке означає «зміну/переінакшення місця». Зазначений концепт репрезентовано на рівні мотиву в значній кількості сучасних британських романів, у яких увиразнено ширший мотив мультикультурності та транскультурності. Проте зафріксована особливість, яка розглянута зокрема i в сучасних британських теоретичних працях на кшталт «The Routledge companion to twenty-first century literary fiction", репрезентує зміну уявлення про архетипи Дороги й Дому як визначальні в більшості сконструйованих художніх реальностей.

У постпостмодерністських романах Дорога асоціюється із самопізнанням i збагаченням, здобуттям нового досвіду й самопізнанням, натомість автентичний, етнічно маркований Діл може містити загрозу для базових щінностей, зокрема й життя. Дисбаланс i непропорційність сощіально-економічного розвитку регіонів планети актуалізує проблему різного ставлення до ціннісних категорій і до такої визначальної категорії, як повага до життя i його захист із боку держави як найвищої цінності. Брак демократичних інститутів i несформованість самої держави постає чинником перегляду («displacement») традиційних архетипних образів.

Вивчення транскультурації стає одним із пріоритетних напрямів вивчення в парадигмі компаративістичних студій. Т. Свербілова в розвідщі «Дискурс транскультуращії та культурної гібридності як предмет літературної компаративістики» пропонує системний i доволі комплексний аналізі цього явища в історії становлення й особливостях фрункціонування як компаративістичної проблеми. Осмислення зазначеної проблеми пов'язане з працями Ф.Ортіса, проте 3 огляду на постульований під час аналізу транскультурації принщип розуміння культурного поля як діалогічного й полілогічного, у якому процес трансляції культурних сенсів мають неодновекторне спрямування, доцільно було б пов'язати або ж принаймні зіставити 3 комунікативними моделями постлассуелівського періоду, у яких 
комунікативний процес репрезентовано як двобічний процес. Попри те, що Т. Свербілова, услід за зарубіжними дослідниками, відходить від трактування транскультуращії як лінгвістичного явища (й питання, що має стосунок до сприйняття культури як перекладного феномену), важливо враховувати зазначену комунікативну специфіку. Крім того, на сучасному етапі окреслене явище позначає не лише процеси, що відбуваються на прикордонних ділянках, а й залучають у своє поле локуси й топоси, що співвідносяться 3 колишніми периферійними зонами імперій (наприклад, Британської), а також із центром територій, що в минулому мали стосунок до імперського центру (Лондон). Т. Свербілова зауважуе, що «категорія культурної гібридизації використовуеться для культур прикордонного типу, де визначається спільна ідентичність, не пов'язана 3 національною, мовною однаковістю (наприклад, Карибська ідентичність)» [4, с. 3]. Зазначена дефініція слушна, проте сьогодні аналізоване явище набувае ще складніших репрезентацій, зокрема в літературі. Ідеться про, як уже було зазначено, трансформацію традищійних уявлень про світ, для якого впродовж значного відрізку часу базовим було сприйняття долу як безпечного простору, як того, що належить до Свого, на відміну від Чужого, асоційованого з небезпеками. Натомість вихід за рамки Свого, репрезентований у низці сучасних британських романів, написаних після 2000-го р., оприявнюе проблему «displacement»/зміщення як один із чинників транскультурації.

Персонажі романів полишають дім, бо він асоціюеться з простором смерті; явища й суспільно-політичні процеси, що мають у ньому місце, небезпечні для життя персонажів. Вони полишають простір Свого і потрапляють у нові світи, у мегаполіси, сконструйовані як іманентно транскультурні, у яких поняття ідентичності не має aprioriмоноетнічної визначеності. Водночас немае підстав говорити про повне розчинення етнічної чи расової ідентичності персонажів, які постають джерелом певних сенсів, що інспірують інших на пошуки сенсу життя 3 урахуванням тих філософських практик, що асоціюються 3 життям цих персонажів-мігрантів або біженців. Подібна тенденція представлена в романі «Там, за зимою» [1] чилійсько-американської письменниці Ісабель Альенде, де дружина одного з головних персонажів оприявнює дискурс африканських вірувань і містичних практик зв’язку фрізичного й метафізичного.

Персонажі, котрі потрапляють у світ мегаполісів (Лондон, НьюЙорк) або ж просторів на протилежному боці Атлантики, відкривають себе нове світорозуміння, водночас постаючи джерелом для 
продукування чуттевості, досвіду, сенсів, які могли бути сформовані в країнах Латинської Америки й Африки, як у романі «Там за зимою» I. Альенде та «Пилюка» Івон Едг'ямбо Овуор. Світосприйняття персонажів виявляе тезу М. Фуко про те, що ли бачило світ так, як нас навчено його бачити. Хоча цей постулат і піддано певній деконструкції: ми бачимо світ так, як нас навчено його бачити + так, як ми бачимо його, потрапивши в нове соціокультурне середовище. Безперечно, Т. Свербілова має ращію, наголошуючи, що процеси транскультурації, услід за М. Требіним, Т. Чернишовою, Ф. Ортісом, Е. Гліссантом, Н. Висоцькою та ін., $е$ багаторівневими й різновекторними, в будь-якому разі ідеться про простір, у якому трансляція сенсів має двовекторний характер. Для персонажа роману «Субота» I. Мак'юена одновимірність світосприйняття, властива певним релігійним угрупованням, стає чинником фрормування франатизму. Релігійний франатизм у «Суботі», на думку Генрі Пероуна, стає чинником глобального, планетарного тероризму як виклику XXI століття.

У сучасному британському романі виникае інший тип проблеми: якщо ми можемо реконструювати специфіку ідентичності Іншого, який потрапляе до мегаполісу з країн Африки, то надзвичайно складно ідентифікувати ідентичність "традищійного» британця, який, умовно кажучи, народився в Лондоні, передмісті або іншому графрстві Англії. Ідентичність такий персонажів часто зображуеться на тлі протиставлень із ідентичністю Іншого, проте вона не має іманентних усталених параметрів, що свідчить про відмову сучасного британського роману від постулювання ідеї англійськості, яка була деконструйована ще в постмодерністському етапі. Не входитиму в площину політичних корелящій зазначеної проблеми, що відсилатимуть до бінома «англійське» - «британське», проте для Генрі в «Суботі» рідний Лондон стає топосом небезпеки через втручання Іншого, точніше Чужого, яким є представники мусульманського релігійного франатизму. Зрештою, простір Свого часто постає внаслідок певних обмежень світом, який не готовий до сприйняття Iнакшості. Кристофер у “Дивному випадку з собакою вночі» М. Геддона мандруе до Лондона: ситуація на вокзалі стає одним із важливих чинників внутрішнього становлення персонажа. Світ Лондона позначений іншим типом урбаністичної моторики, кажучи метафорично, іншою швидкістю транспортних i соціальних процесів. Водночас саме така пришвидшена динаміка не дає можливості замикатися на Іншому, котрий має певні вади або ж не є таким, як більшість. 
Висновки... Дискурс транскультурації впливає на ансамбль тем і мотивів, експлікованих у сучасних англомовних романах. Можливість впровадження транскультураційної доктрини передбачае, що кожний учасник сощіокультурного та політичного простору має цінність для формування спільного культурного середовища, кожний має право здобути гідне життя відповідно до концепції Global Care, що передбачає етичну відповідальність усіх гравців за глобальні трансформації. Водночас ідеться про етичність принципів, покладених в основу комунікації між різними суб'єктами геополітичного та соціокультурного простору. Мотив міграції, детермінований загрозою життю персонажів у межах рідного долу, трансформуе архетипний образ Дому, елімінуючи 3 нього поняття захисту та безпеки. Натомість зовнішній відкритий простір, який має вищий соціально-економічний рівень розвитку, постае фрундаментом, на якому вихідці 3 африканських або латиноамериканських країн мають можливість сформувати гідне життя. Дискурс транскультурації, експлікований у літературних творах, позначається на трансформації архетипу Долу (й також Дороги), що дає підстави для уточнення теорії архетипів транскультураційного періоду, якому притаманна гібридність, культурна неоднорідність, етика поваги до Іншого, трансферність сенсів, досвіду, життесвіту й культурних кодів задля формування концепції планетарного й глобального існування людства. Суспільнополітичні зміни впливають на простір літератури, позначаючись на зміні таких базових ціннісних концептів, як категорія архетипу.

\section{Список використаних джерел і літератури:}

1. Альенде I. Там, за зимою: роман ; пер зісп. Сергій Борщевський. К.: Видавництво Анетти Антоненко, 2018. 360 с.

2. Дроздовський Д. Дискурс суб’ектності в англійському постпостмодерністському романі. Науковий вісник Міжнародного гуманітарного університету. Серія: Філологія. 2019. Випуск 38. С. 194-198.

3. Мірошниченко Л.Я. Скептицизм Сократа і сучасний англійський роман. Від бароко до постлодернізму: збірник наукових праць. 2013. Том 17. №2. C. 119-125.

4. Свербілова Т. Дискурс транскультурації та культурної гібридності як предмет літературної компаративістики.

URL: https://www.academia.edu/38002133/\%D0\%94\%D0\%98\%D0\%A1\%D0\%9A\%D0\%A3 \%D0\%A0\%D0\%A1_\%D0\%A2\%D0\%A0\%D0\%90\%D0\%9D\%D0\%A1\%D0\%9A\%D0\%A 3\%D0\%9B\%D0\%AC\%D0\%A2\%D0\%A3\%D0\%A0\%D0\%90\%D0\%A6\%D0\%86\%D0\%87 _\%D0\%A2\%D0\%90_\%D0\%9A\%D0\%A3\%D0\%9B\%D0\%AC\%D0\%A2\%D0\%A3\%D0\% A0\%D0\%9D\%D0\%9E\%D0\%87_\%D0\%93\%D0\%86\%D0\%91\%D0\%A0\%D0\%98\%D0\% 
94\%D0\%9D\%D0\%9E\%D0\%A1\%D0\%A2\%D0\%86.pdf (дата звернення 07.12.2019).

5. Mohsin Hamid. Exit West: A Novel. New York: Hamish Hamilton, Riverhead Books, 2017. 256 p.

6. Robinson F. Global care ethics: beyond distribution, beyond justice. Journal of Global Ethics. Volume 9, 2013. Issue 2: Critical Approaches to Global Justice: At the Frontier. P. 131-143. URL: https://www.tandfonline.com/doi/abs/10.1080/17449626.2013.818466. (дата звернення 07.12.2019). https://doi.org/10.1080/17449626.2013.818466

7. Robinson F. The importance of care in the theory and practice of human security. Journal of International Political Theory. 4 (2). P. 167-188URL: https://journals.sagepub.com/doi/abs/10.3366/e1755088208000207(дата звернення 07.12.2019).

8. The contemporary British novel since 2000; edited by James Acheson. Edinburgh: Edinburgh University Press, 2017.214 p.

9. The Routledge companion to twenty-first century literary fiction; edited by Daniel O'Gorman and Robert Eaglestone. London-New York: Routledge, 2019. 474 p.

10. Yvonne Adhiambo Owuor. Dust. Kwani Trust, 2013. 385 p.

\section{References:}

1. Aliende I. Tam, za zymoiu: roman ; per z isp. Serhii Borshchevskyi. Kyiv: Vydavnytstvo Anetty Antonenko, 2018. 360 p.

2. Drozdovskyi D. Dyskurs subiektnosti v anhliiskomu postpostmodernistskomu romani. Naukovyi visnyk Mizhnarodnoho humanitarnoho universytetu. Seriia: Filolohiia. 2019. Vypusk 38. Pp. 194-198.

3. Miroshnychenko L. Ya. Skeptytsyzm Sokrata i suchasny ianhliiskyi roman. Vid baroko do postmodernizmu: zbirnyk naukovykh prats. 2013. Vol. 17. №2. Pp. 119-125.

4. Sverbilova T. Dyskurs transkulturatsii ta kulturnoi hibrydnosti yak predmet literaturnoi komparatyvistyky. URL: https://www.academia.edu/38002133/\%D0\%94\%D0\%98\%D0\%A1\%D0\%9A\%D0\%A3 \%D0\%A0\%D0\%A1_\%D0\%A2\%D0\%A0\%D0\%90\%D0\%9D\%D0\%A1\%D0\%9A\%D0\%A 3\%D0\%9B\%D0\%AC\%D0\%A2\%D0\%A3\%D0\%A0\%D0\%90\%D0\%A6\%D0\%86\%D0\%87 _\%D0\%A2\%D0\%90_\%D0\%9A\%D0\%A3\%D0\%9B\%D0\%AC\%D0\%A2\%D0\%A3\%D0\% A0\%D0\%9D\%D0\%9E\%D0\%87_\%D0\%93\%D0\%86\%D0\%91\%D0\%A0\%D0\%98\%D0\% 94\%D0\%9D\%D0\%9E\%D0\%A1\%D0\%A2\%D0\%86.pdf (accessed 07.12.2019).

5. Mohsin Hamid. Exit West: A Novel. New York: Hamish Hamilton, Riverhead Books, 2017. 256 p.

6. Robinson F. Global care ethics: beyond distribution, beyond justice. Journal of Global Ethics. Volume 9, 2013. Issue 2: Critical Approaches to Global Justice: At the Frontier. Pp. 131-143. URL: https://www.tandfonline.com/doi/abs/10.1080/17449626.2013.818466(accessed 07.12.2019). https://doi.org/10.1080/17449626.2013.818466

7. Robinson F. The importance of care in the theory and practice of human 
security. Journal of International Political Theory. 4 (2). P. 167-188URL: https://journals.sagepub.com/doi/abs/10.3366/e1755088208000207(accessed 07.12.2019).

8. The contemporary British novel since 2000; edited by James Acheson. Edinburgh: Edinburgh University Press, 2017.214 p.

9. The Routledge companion to twenty-first century literary fiction; edited by Daniel O'Gorman and Robert Eaglestone. London-New York: Routledge, 2019. $474 \mathrm{p}$.

10. Yvonne Adhiambo Owuor. Dust. KwaniTrust, 2013. 385 p.

\section{Summary \\ Dmytro Drozdovskyi}

\section{Discourse of Transculturation in the Contemporary British Novels:} Revision of Home as an Archetype

The theory of transculturality (F. Ortiz) is of particular importance in the field of contemporary literary criticism and cultural studies, the objects of which are hybrid cultural phenomena. Transculturalism replaces multiculturalism, which does not imply the transfer of meanings, values, experiences, cultural phenomena, etc., but only confirms their presence in one geopolitical and socio-cultural field. Transculturality makes it possible to view cultural artifacts as complex phenomena, marked by immanent heterogeneity and homogeneity, which at the same time provides particular creative value and cultural significance of such phenomena. In the domestic and foreign literary studies, the outlines of the phenomena of transculturation are presented in the works of H. Bhabha, I. Orzhytskyi, T. Sverbilova, M. Tlostanova, and others. However, most often the studios provide a historical overview of the forms of discourse transculturation and the basic theoretical concepts (ideas) implemented in the context of this phenomenon. The proposed article, which is an attempt to develop ideas that are relevant to the discourse of transculturation, is about defining the archetype of the House as defining in the literature of the concept and at the same time one that is marked today by the influence of transculturation, which leads to the shifting of the immanent essence of this archetype in modern English-speaking English USA. Transformations are subject to such basic notions that correlate with the archetype of the House as security, protection, comfort, and so on. In novels written after the year 2000, going beyond one's own ethnic space enables the characters to reach a new level of social security, guaranteeing the value of their own lives, while being within the locus of the home is marked by the dangers and potential threats to life. The article deals with the transformation of the basic archetype of world culture and literature in the paradigm of post-modernism. Replacing the immanent features of the House archetype is in line with the concept of "displacement", widely represented in contemporary British theory of literature.

Key words: archetype of Home, transculturation, hybridity, literary theory, contemporary English language novel, British novel.

Дата надходження статті: «16» жовтня 2019 р.

Дата прийняття до друку: «21» листопада 2019 р. 